\title{
COMMENTARY
}

\section{Antarctic subglacial lake exploration: a new frontier in microbial ecology}

\author{
DA Pearce
}

The ISME Journal (2009) 3, 877-880; doi:10.1038/ ismej.2009.53; published online 11 June 2009

To date, wherever life has been sought on Earth, it has almost always been found-from high in the stratosphere (Imshenetskii et al., 1975, 1978, 1986; Wainwright et al., 2003) to deep in the ocean trenches (Takamia et al., 1997; D’Hondt et al., 2004) and even within the Earth's crust itself (Pedersen, 2000). Microorganisms have also been found in some of the most extreme environments. They have been found to exist in ice, boiling water, acid, salt crystals, toxic waste and even in the water cores of nuclear reactors (Rothschild and Mancinelli, 2001).

Antarctic subglacial lake ecosystems have the potential to be one of the most extreme environments on Earth, with combined stresses of high pressure, low temperature, permanent darkness, low-nutrient availability and oxygen concentrations derived from the ice that provided the original meltwater (Siegert et al., 2003), where the predominant mode of nutrition is likely to be chemoautotrophic. Yet, to date, the identification of significant subglacial bacterial activity in the Arctic, beneath glaciers (Skidmore et al., 2000, 2005) and in subglacial lakes (Gaidos et al., 2004), as well as extensive work on permafrost communities and work in the deep sea, suggests that life can survive and potentially thrive in these types of environment. Microbial life has been shown to function at gigapascal pressures (Sharma et al., 2002) and bacteria recovered from the deep ocean at around $4000 \mathrm{~m}$ have been shown to retain both structural integrity and metabolic activity. They have shown activity in the Antarctic at $-17^{\circ} \mathrm{C}$ (Carpenter et al., 2000) and to exist in the pore spaces between ice crystals (Thomas and Dieckmann, 2002).

It has been established for some time that viable microbial life is found in glacial ice, although estimates vary widely by study, geographical location and procedure-from less than one viable cell $\mathrm{ml}^{-1}$ in polar ice (Abyzov et al., 1982) to $6 \times 10^{7}$ cells ml $^{-1}$ in a Greenland ice core (Sheridan et al., 2003). The identification of significant alpine subglacial bacterial activity has already been observed (Sharp et al., 1999), and distinct bacterial communities have been characterized from beneath
Arctic glaciers (Bhatia et al., 2006). Elsewhere, viable microorganisms have been recovered from 1 million-year-old Antarctic permafrost (Kochkina et al., 2001), which makes it likely that prolonged preservation of viable microorganisms may be prevalent in Antarctic ice-bound habitats. Thus, existing data strongly suggests that the Antarctic ice sheet may harbour a time-specific microbiological seed bank, which could provide a source of microorganisms to inoculate subglacial environments.

The Antarctic subglacial environment described so far consists of around 145 subglacial lakes and their interconnected watercourses (Siegert, 2005; Siegert et al., 2005; Priscu et al., 2008), although new lakes continue to be identified (Popov and Masolov, 2007; Peters et al., 2008). In Antarctic subglacial systems, $100 \mathrm{cells} \mathrm{ml}^{-1}$ (glacial ice) and 400 cells $\mathrm{ml}^{-1}$ (accretion or glacial transition zone ice) have been estimated from the ice above Lake Vostok (Priscu et al., 2008). Indeed, all samples in this accretion ice between 3541 and $3611 \mathrm{~m}$ depth were found to contain both prokaryotic and eukaryotic microorganisms (Priscu et al., 1999; Price, 2000; Poglazova et al., 2001; Christner et al., 2001), and functional groupings have even been described, such as the thermophilic chemoautotrophic Hydrogenophilus thermoluteolus (Lavire et al., 2006). More recently, microbes have been detected in sediments collected from beneath the West Antarctic Ice Sheet (Lanoil et al., 2009) so the potential for microbial life in Antarctic subglacial lake systems is clear.

The estimated time of migration of microorganisms through the ice into Antarctic subglacial lakes, is of the order of 10000-50000 years-not long enough for the evolution of completely new species, but certainly long enough for novel biochemical, physiological and morphological diversity to potentially exist, or for the continued existence of relic populations that may have become extinct elsewhere. In such an extreme environment, the mere presence of life in itself would be a major scientific discovery, but there are reasons to expect that such microorganisms would possess special or unique adaptations to this unusual and potentially hostile environment. Analysis of the metabolic activity and capability or new physiologies (using a metagenomic or high-throughput sequencing approach) 
and bioenergetics through the analysis of biochemical pathways of returned samples, will help to gain a better understanding of the potential role of such subglacial lake microorganisms in biogeochemical cycling and in their functioning and control of ecosystem processes, or indeed their biotechnological potential (Raymond et al., 2008). In addition, the climate record locked in subglacial lake sediments has the potential to provide unique insights into past changes in ecosystem function and adaptation.

With the advent of molecular techniques, microbial ecology has entered a golden age of advancement and discovery. We have also reached the point at which technology can tackle one of the final frontiers of exploration in the search for life on Earth. It is now financially, logistically and practically possible to study Antarctic subglacial lake systems. Significant challenges still remain, however, particularly with respect to obtaining samples from such a remote and hostile environment, while preventing contamination (Vincent, 1999) of both the samples themselves and the subglacial environment (either microbiologically or chemically)particularly as Antarctic subglacial lake systems are believed to be hydraulically interconnected (Price et al., 2002), and in the unambiguous interpretation of microbiological material obtained. However, progress is being made on each of these fronts: resources have been made available for access at Lake Vostok and Lake Ellsworth www.nerc. ac.uk/press/releases/2009/03-ellsworth.asp (Figure 1), methods are already under development in analogous systems to effectively sample these environments (Doran et al., 2008), particularly with respect to the potential for contamination (Alekhina et al., 2006) and an initial assessment has already been made on what is needed to responsibly explore Antartic subglacial lake environments (National Research Council, 2007).

We are now, therefore, in a position to ask some very interesting questions of these systems, such as: do the Antarctic subglacial lake environments contain life, and if so, what, where and how? What can subglacial lake microorganisms tell us about the distribution and evolution of microbial life in on Earth? What are the biogeochemical resources of this unique gene pool? What unique historical climate change record is locked within subglacial lake sediments, and how do Antarctic subglacial lakes interact with and influence the overlying ice sheet? To address these questions, developments and improvements in key techniques can now be

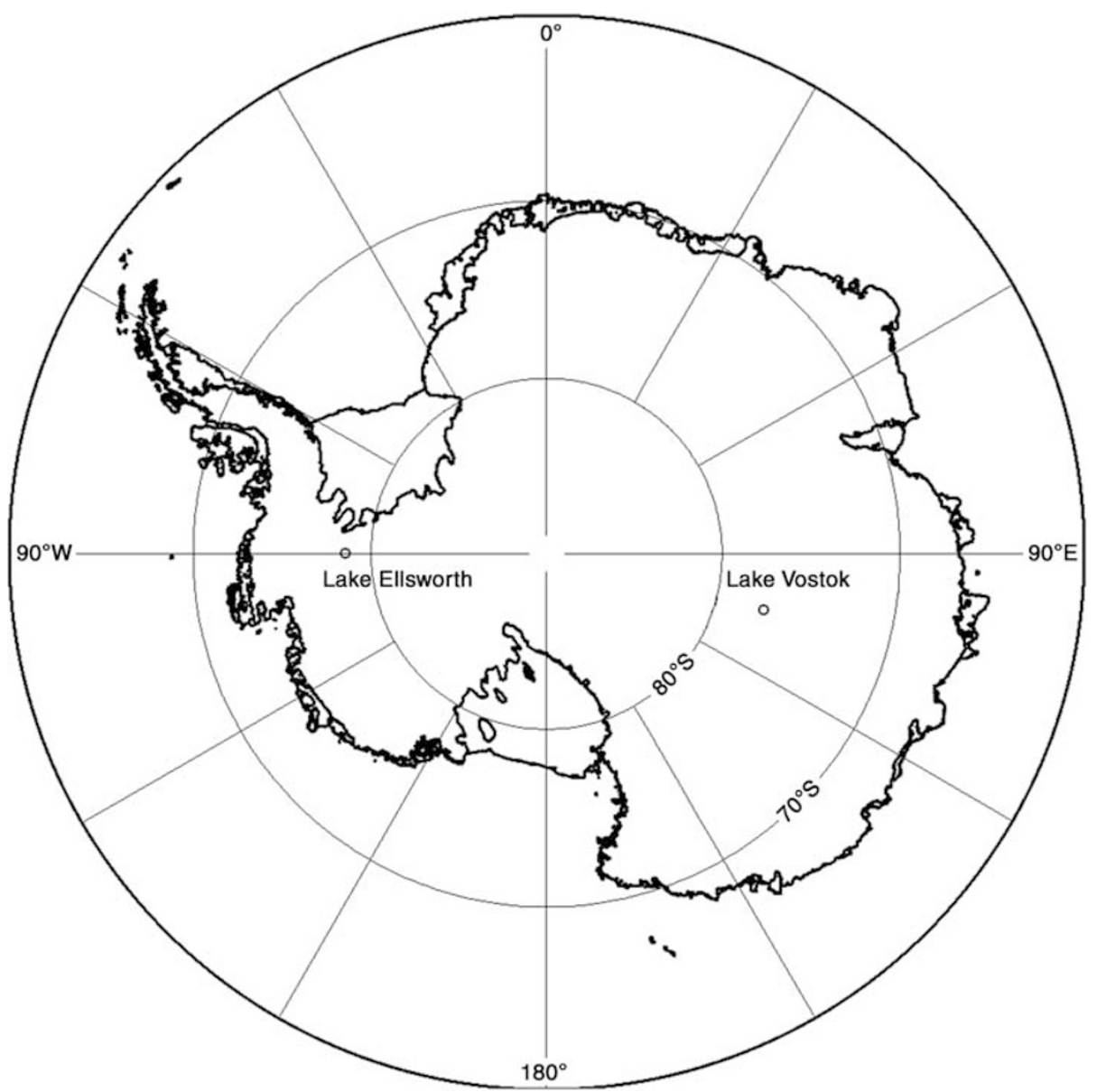

Figure 1 The location of Lake Ellsworth and Lake Vostok in West and East Antarctica, respectively. 
applied to subglacial lake samples. These include: microscopy; fluorescent and electron microscopy (linked to specific gene probes), molecular biology; genomic DNA extracted from material obtained and used to construct metagenomic libraries (to screen for new physiologies), physiology and biochemistry (to investigate biogeochemical cycling), direct culture and biomarkers or tracers (Wackett, 2007).

Advances in molecular technology have vastly improved life detection limits, such that microscopy and PCR are now capable of detecting individual cells per ml, or the DNA itself at $0.1-0.2 \mu \mathrm{l}^{-1}$. To date, 16S rDNA-based community reconstruction has shown sequences between 6-93 from Lake Vostok accretion ice (though this figure is known to include contaminants). Adopting a culture-based approach from Antarctic ice cores, 0, 2 and $10 \mathrm{cfu} \mathrm{ml}^{-1}$ have been isolated from Dyer Plateau, Siple Station and Taylor Dome respectively (Christner et al., 2000), and 1-16 cfu $\mathrm{ml}^{-1}$ from a Dronning Maud Land ice core (Pearce, unpublished data). Radiolabelled substrates can yield uptake rates at the level of several hundred cells (Karl et al., 1999). However, not one approach is likely to provide a complete unbiased picture of the microorganisms residing in a sample or their relative numbers, and the design of specific, clean sampling strategies is extremely important.

Although Antarctic subglacial lakes were identified almost 40 years ago (Robin et al., 1970), we are only now at a stage where the exploration of Antarctic subglacial ecosystems is a reality, and this will open a new frontier in microbial ecology. Initial results from Lake Vostok accretion ice, access into Arctic subglacial lakes and preliminary work with shallow Antarctic subglacial systems, suggests we are about to enter an exciting phase in Antarctic subglacial lake research. Perhaps most significantly, if Antarctic subglacial lake ecosystems are found to be sterile, it would be a major discovery in itself.

$D$ Pearce is at British Antarctic Survey, Natural Environment Research Council, Cambridge, UK. E-mail: dpearce@bas.ac.uk

\section{References}

Abyzov SS, Lipenkov VY, Bobin NE, Kudryashov BB. (1982). Microflora of central Antarctic glacier and methods for sterile ice-core sampling for microbiological analyses. Biol Bull Acad Sci USSR 9: 304-349.

Alekhina IA, Marie D, Petit JR, Lukin VV, Zubkov VM, Bulat SA. (2006). Molecular analysis of bacterial diversity in kerosene-based drilling fluid from the deep ice borehole at Vostok, East Antarctica. FEMS Micro Ecol 59: 289-299.

Bhatia M, Sharp M, Foght J. (2006). Distinct bacterial communities exist beneath a high arctic polythermal glacier. Appl Environ Microbiol 72: 5838-5845.

Carpenter EJ, Lin S, Capone DG. (2000). Bacterial activity in South Pole snow. Appl Environ Microbiol 66: $4514-4517$.
Christner BC, Mosley-Thompson E, Thompson LG, Reeve JN. (2001). Isolation of bacteria and $16 \mathrm{~S}$ rDNAs from Lake Vostok accretion ice. Environ Microbiol 3: 570-577.

Christner BC, Mosley-Thompson E, Thompson LG, Zagorodnov V, Sandman K, Reeve JN. (2000). Recovery and identification of viable bacteria immured in glaical ice. Icarus 144: 479-485.

D’Hondt S, Jørgensen B-B, Miller DJ, Batzke A, Blake R, Cragg BA et al. (2004). Distributions of microbial activities in deep sub-seafloor sediments. Science 306: 2216.

Doran PT, Fritsen CH, Murray AE, Kenig F, Mckay CP, Kyne JD. (2008). Entry approach into pristine icesealed lakes-Lake Vida, East Antarctica, a model ecosystem. Limn Oceanogr Meth 6: 542-547.

Gaidos E, Lanoil B, Thorsteinsson T, Graham A, Skidmore M, Han S-K et al. (2004). A viable microbial community in a subglacial volcanic crater lake, Iceland Astrobiol 4: 327-344.

Imshenetskii AA, Lysenko SV, Kazakov GA. (1975). Microorganisms of stratosphere. Doklady Akademii Nauk SSSR 224: 223-225.

Imshenetskii AA, Lysenko SV, Kazakov GA. (1978). Upper boundary to the biosphere. Appl Environ Microbiol 35: $1-5$.

Imshenetskii AA, Lysenko SV, Petrukhina TY, Sizova TP. (1986). Systematic position of microorganisms isolated from the stratosphere and mesosphere. Microbiol 55: 96-98.

Karl DM, Bird DF, Björkman K, Houlihan T, Shackelford R, Tupas L. (1999). Microorganisms in the accreted ice of Lake Vostok, Antarctica. Science 286: 2144-2147.

Kochkina GA, Ivanushkina NE, Karasev SG, Gavrish EY, Gurina LV, Evtushenko LI et al. (2001). Survival of micromycetes and actinobacteria under conditions of long-term natural cryopreservation. Microbiol 70: 356-364.

Lanoil B, Skidmore M, Priscu JC, Han S, Foo W, Vogel SW et al. (2009). Bacteria beneath the West Antarctic Ice Sheet. Environ Microbiol 11: 609-615.

Lavire C, Normand P, Alekhina I, Bulat S, Prieur D, Birrien JL et al. (2006). Presence of Hydrogenophilus thermoluteolus DNA in accretion ice in the subglacial Lake Vostok, Antarctica, assessed using rrs, cbb and hox. Environ Microbiol 8: 2106-2114.

National Research Council (2007). Exploration of Antarctic Subglacial Aquatic Environments: Environmental and Scientific Stewardship. NRC Press: Washington DC, USA, 152pp.

Pedersen K. (2000). Exploration of deep intraterrestrial microbial life: current perspectives. FEMS Microbiol Lett 185: 9-16.

Peters LE, Anandakrishnan S, Holland CW, Horgan HJ, Blankenship DD, Voigt DE. (2008). Seismic detection of a subglacial lake near the South Pole, Antarctica. Geophys Res Lett 35: doi:10.1029/2008GL035704.

Poglazova MN, Mitskevich IN, Abyzov SS, Ivanov MV. (2001). Microbiological characterization of the accreted ice of subglacial Lake Vostok, Antarctica. Microbiol 70: 723-730.

Popov SV, Masolov VN. (2007). Forty-seven new subglacial lakes in the 0-110 degrees E sector of East Antarctica. J Glaciol 53: 289-297.

Price PB. (2000). A habitat for psychrophiles in deep Antarctic ice. Proc Nat Acad Sci USA 97: 1247-1251. 
Price PB, Nagornov OV, Bay R, Chirkin D, He YD, Miocinovic $\mathrm{P}$ et al. (2002). Temperature profile for glacial ice at the South Pole: Implications for life in a nearby subglacial lake. Proc Nat Acad Sci USA 99: 7844-7847.

Priscu JC, Adams EE, Lyons WB, Voytek MA, Mogk DW, Brown RL et al. (1999). Geomicrobiology of subglacial ice above Lake Vostok, Antarctica. Science 286: 2141-2144.

Priscu JC, Tulaczyk S, Studinger M, Kennicutt II MC, Christner BC, Foreman CM. (2008). Antarctic subglacial water: origin, evolution and ecology. In: Vincent WF, Laybourn-Parry J (eds). Polar Lakes and Rivers-Limnology of Arctic and Antarctic Aquatic Ecosystems. Oxford University Press: UK, pp 119-135.

Raymond JA, Christner BC, Schuster SC. (2008). A bacterial ice-binding protein from the Vostok ice core. Extremophiles 12: 713-717.

Robin GDQ, Swithinbank CWM, Smith BME. (1970). Radio echo exploration of the Antarctic ice sheet. International Symposium on Antarctic Glaciological Exploration (ISAGE), Hanover, New Hampshire, USA, 3-7 September, 1968.

Rothschild LJ, Mancinelli RL. (2001). Life in extreme environments. Nature 409: 1092-1101.

Sharma A, Scott JH, Cody GD, Fogel ML, Hazen RM, Hemley RJ et al. (2002). Microbial activity at gigapascal pressures. Science 295: 1514.

Sharp M, Parks J, Cragg B, Fairchild I, Lamb H, Tranter M. (1999). Widespread bacterial population at glacier beds and their relationship to rock weathering and carbon cycling. Geology 27: 107-110.

Sheridan PP, Miteva VI, Brenchley JE. (2003). Phylogenetic analysis of anaerobic psychrophilic enrich- ment cultures obtained from a Greenland glacier ice core. Appl Environ Microbiol 69: 2153-2160.

Siegert MJ, Tranter M, Ellis-Evans JC, Priscu JC, Lyons WB. (2003). The hydrochemistry of Lake Vostok and the potential for life in Antarctic subglacial lakes. Hydrol Process 17: 795-814.

Siegert MJ. (2005). Lakes beneath the ice sheet: The occurrence, analysis, and future exploration of Lake Vostok and other Antarctic subglacial lakes. Ann Rev Earth Planet Sci 33: 215-245.

Siegert MJ, Carter S, Tabacco I, Popov S, Blankenship DD. (2005). A revised inventory of Antarctic subglacial lakes. Ant Sci 17: 453-460.

Skidmore ML, Foght JM, Sharp MJ. (2000). Microbial life beneath a high arctic glacier. Appl Environ Microbiol 66: $3214-3220$.

Skidmore ML, Anderson SP, Sharp M, Foght JM, Lanoil BD. (2005). Comparison of microbial community compositions of two subglacial environments reveals a possible role for microbes in chemical weathering processes. Appl Environ Microbiol 71: 6986-6997.

Takamia H, Inouea A, Fujia F, Horikoshia K. (1997). Microbial flora in the deepest sea mud of the Mariana Trench. FEMS Microbiol Lett 152: 279-285.

Thomas DN, Dieckmann GS. (2002). Antarctic sea icea habitat for extremophiles. Science 295: 5555.

Vincent WF. 1999. Icy life on a hidden lake. Science $\mathbf{2 8 6}$ : 2094-2095.

Wackett LP. (2007). Microbial biomarkers. Environ Microbiol 9: 836-837.

Wainwright M, Wickramasinghe NC, Narlikar JV, Rajaratnam P. (2003). Microorganisms cultured from stratospheric air samples obtained at $41 \mathrm{~km}$. FEMS Microbiol Lett 218: 161-165. 